\title{
Hardly Accessible Morphological Structures - Geological Mapping and Accuracy Analysis of SfM and TLS Surveying Technologies
}

\author{
Katarína PUKANSKÁ1, Karol BARTOŠ ${ }^{1^{*}}$, Andrej HIDEGHÉTY ${ }^{2}$, Klaudia KUPČÍKOVÁ \\ Lubomír KSE NAK ${ }^{1}$, Juraj JANOČKO ${ }^{3}$, Marcin GIL ${ }^{4}$, Pawel FRACKIEWICZ ${ }^{4}$, \\ Marta PREKOPOVÁ ${ }^{3}$, Igor ĎURISKA ${ }^{3}$ and Jozef MIŽÁK ${ }^{5}$
}

\author{
Authors' affiliations and addresses: \\ ${ }^{1}$ Technical University of Košice, Institute of Geodesy, \\ Cartography and GIS, Park Komenského 19, 04200 \\ Košice, Slovakia \\ e-mail: katarina.pukanska@tuke.sk, \\ karol.bartos@tuke.sk, lubomir.ksenak@tuke.sk \\ ${ }^{2}$ Slovak University of Technology in Bratislava, Faculty \\ of Civil Engineering, Radlinského 11, \\ 81005 Bratislava, Slovakia \\ e-mail: andrej.hideghety@stuba.sk \\ ${ }^{3}$ Technical University of Košice, Institute of \\ Geosciences, Park Komenského 15, 04200 Košice, \\ Slovakia \\ e-mail: klaudia.kupcikova@tuke.sk, \\ juraj.janocko@tuke.sk, igor.duriska@tuke.sk \\ marta.prekopova@tuke.sk, \\ ${ }^{4}$ Kielce University of Technology, Faculty of \\ Environmental, Geomatic and Energy Engineering, al. \\ Tysiąclecia Państwa Polskiego 7 25-314 Kielce, Poland \\ e-mail: marcingil@tu.kielce.pl, \\ pfrackiewicz@tu.kielce.pl \\ ${ }^{5}$ State Geological Institute of Dionýz Štúr, Department \\ of Geofond, Mlynská dolina 1, 81704 Bratislava 11 \\ e-mail: jozef.mizak@geology.sk \\ *Correspondence: \\ Karol Bartoš, Technical University in Košice, Institute of \\ Geodesy, Cartography and GIS, Park Komenského 19, \\ 04200 Košice, Slovakia \\ tel.: +42155602 2978 \\ e-mail: karol.bartos@tuke.sk
}

Funding information:

Grant No. 1/0844/18 by VEGA

Grant No. 004TUKE-4/2019 by KEGA

Grant No. 06/TUKE/2020 by TUKE

How to cite this article:

Pukanská, K., Bartoš, K., Hideghéty, A., Kupčíková, K., Kseňak, L., Janočko, J., Gil, M., Frackiewicz, P.,

Prekopová, M., Duriska, I, and Mižák, J. (2020). Hardly Accessible Morphological Structures - Geological Mapping and Accuracy Analysis of SfM and TLS Surveying Technologies, Acta Montanistica Slovaca, Volume 25 (4), 479-493

DOI:

https://doi.org/10.46544/AMS.v25i4.04

\begin{abstract}
The aim of geological field mapping is to collect and interpret data on the relief of the Earth's surface. From thus created geological maps, we can obtain information about mineral units and their structure - rock and mineral types, their thickness, lithological deposits, faults, folds, fractures, and thus interpret information as they originated over time. However, the accessibility of such structures is affected by various morphological elements - terrain notches, watercourses, but also by vegetation. Simultaneous geodetic and geological mapping could be a solution for surveying hardly accessible morphological structures. Non-contact surveying technologies - terrestrial laser scanning (TLS) and close-range photogrammetry (terrestrial and remotely piloted aircraft system (RPAS) photogrammetry) provide reliable, high-quality and accurate data on the topographic surface with a high temporal resolution, as the spatial accuracy of the measured point can be $m_{X Y Z}$ $\leq 10 \mathrm{~mm}$ at an imaging distance of about $20-30 \mathrm{~m}$. From the measured data, it is possible to generate point clouds, digital terrain models, and orthophoto maps based on automated data processing. However, the disadvantage of photogrammetric imaging is a proportional decrease in accuracy with increasing imaging distance. The accuracy of TLS is not significantly affected by increasing distance. The paper presents a case study of the use and comparison of non-contact surveying technologies and their application for insitu mapping of hardly accessible geological structures in the area of Spišská Magura (Slovak-Polish border). The results are given for two localities on two outcrops - Jurgów (PL) and Bachledova valley (SK), while analyzing the usability of TLS and RPAS photogrammetry, with and without the use of artificial ground control points (GCP). The paper presents a mutual comparison of all obtained graphical outputs in terms of $1 \mathrm{D}$ and $2 \mathrm{D}$ quality depending on the type of GCPs used, depending on the terrain and accessibility. The results show that by using photogrammetry when creating map data, in comparison with TLS, we are able to get sufficient accuracy of outputs for in-situ geological mapping.
\end{abstract}

\section{Keywords}

photogrammetry, laser scanning, surveying, structural analysis,

Central Carpathian Paleogene Basin, Spišská Magura region 


\section{Introduction}

Within the frame of the Entrepreneurship course and practical geology/ geodesy/ mineral processing field education organized by the Faculty of Mining, Ecology, Process Control and Geotechnologies of the Technical University of Košice, geological research of rock massifs was performed in order to characterize the tectonic structures of the selected areas in the Spišská Magura region in Slovakia and neighbouring Podhale region in Poland (Fig. 1). For this purpose, an interdisciplinary approach was chosen where geological field observations were supplemented with non-selective geodetic methods. Non-selective geodetic techniques are some of the most used methods when an object is either physically inaccessible or must be documented with high resolution.

The paper's main aim is to explore the accuracy of photogrammetric models and present a contribution of these models to the geological-structural analysis of the rock massifs. The digital photogrammetry, often supplemented by TLS, has been successfully employed in the field of structural geology (Roncella et al., 2004), for example, for orientation measurements of bedding and fractures of rocks exposed along coastal outcrops (Vollgger and Cruden, 2016), interpretation of brittle and ductile structures (Vollgger and Cruden, 2016), visualization the complex of tectonic structures of an outcrop (Bistacchi et al., 2015), topographic surveys of small areas (Blistan et al., 2019), mapping of debris flows (Fraštia et al., 2019), a survey of complex topographical and morphological structures (Gallay et al., 2016), mapping post-mining sites (Urban et al., 2018), mapping folds and fractures (Menegoni et al., 2018), and even for high-resolution mapping of geoglyphs (Pavelka, Šedina and Matoušková, 2018).

Digital photogrammetry, using the Structure from Motion (SfM) (Cipolla, 2008; Clini et al., 2016; Schönberger and Frahm, 2016) algorithm facilitates the image-based 3D modelling of a given object provided that the structure is visible on at least two photos taken from different camera stations and the texture is variable. The process is based on computer vision; feature detection algorithms, for example, Scale Invariant Feature Transform (SIFT) (Ke and Sukthankar, 2004; Lowe, 2004; Mach, 2012; Joglekar et al., 2014), detection of identical points on a set of images and the calculation the relative orientation parameters based on robust estimation techniques, for example, RANdom SAmple Consensus (RANSAC) (Fischler and Bolles, 1981) and epipolar geometry (Fusiello and Irsara, 2011). Bundle adjustment and self-calibration are also included (Triggs et al., 1999; Honti and Erdélyi, 2017). Measuring rock massifs using such technique results in high-resolution outputs such as dense point clouds, spatial 3D polygonal models and orthomosaics. For the verification of such measurements performing TLS is suitable thanks to its capabilities of distance measurement and the production of similar point clouds. The main advantage of photogrammetry compared to TLS is its price, as a digital camera combined with photogrammetric software is less expensive and the possibility of placing the camera to inaccessible places using an RPAS system. Another advantage is a higher resultant resolution if the images are taken up close. Photogrammetry performs worse in conditions where the object is not sufficiently lit or has a flat texture, which was not the case in the given circumstances. TLS, on the other hand, can perform distance measurements and measurements in dark places. TLS also applies a non-selective approach where the measured points are distributed as an irregular raster and are defined using the spatial polar method (Honti and Erdélyi, 2017). The rise of affordable and consumer-friendly RPAS systems was the next milestone of photogrammetry since these systems are usually equipped with high-resolution $4 \mathrm{~K}$ cameras and mechanical image stabilizers. Thus, the internal equipment facilitates the acquisition of a steady and sharp image, even in a windy environment.

\section{Study area}

The study was performed at two localities in the Spišská Magura region in Slovakia and adjacent Podhale region in Poland belonging to the Central Carpathian Paleogene Basin (CCP Basin). The CCP Basin is the largest Paleogene basin in the Central Western Carpathians developed during the collision between the European Platform and the Alps-Carpathians-Pannonia (ALCAPA) (Csontos and Vörös, 2004). The sedimentary fill of the basin consists of the Subtatric Group subdivided into four formations reflecting different phases of the basin evolution: Borové Fm., Huty Fm., Zuberec Fm., and Biely Potok Fm. (Gross et al., 1984). In Poland, the continuation of the CCP basin is called Podhale basin, and the equivalent of the Subtatric Group is Podhale flysch divided into four informal lithostratigraphic units: the Szaflary, Zakopane, Chocholów and Ostrysz beds (Anczkiewicz et al., 2013). The lowermost, Borové Fm. is represented by Paleocene to Oligocene continental, deltaic and shallow-marine deposits transgressively overlying the basement of the basin (Janočko et al., 2000). Lying above them are Huty Fm. characterized by several lithologic units in the studied area. The units are from the base upward as follows:

- mudstones with occasional intercalations of sandstones and conglomerates,

- Tokáreň conglomerates - conglomerates and sandstones deeply incised into underlying mudstones thick up to $240 \mathrm{~m}$,

- mudstones with occasional beds of conglomerates and sandstones,

- Bachleda sandstones - amalgamated beds of sandstone thick up to $8 \mathrm{~m}$, 
- $\quad$ mudstones with minor conglomerate and sandstone beds.

The Huty Fm. is overlain by the Zuberec Fm. consisting of alternating mudstone and sandstone beds. The youngest formation of the CCP Basin - Biely Potok Fm. (Oligocene - Early Miocene) is mostly composed of coarse-grained sandstones and minor conglomerates (Gross et al.,1984) and does not occur in the studied area.

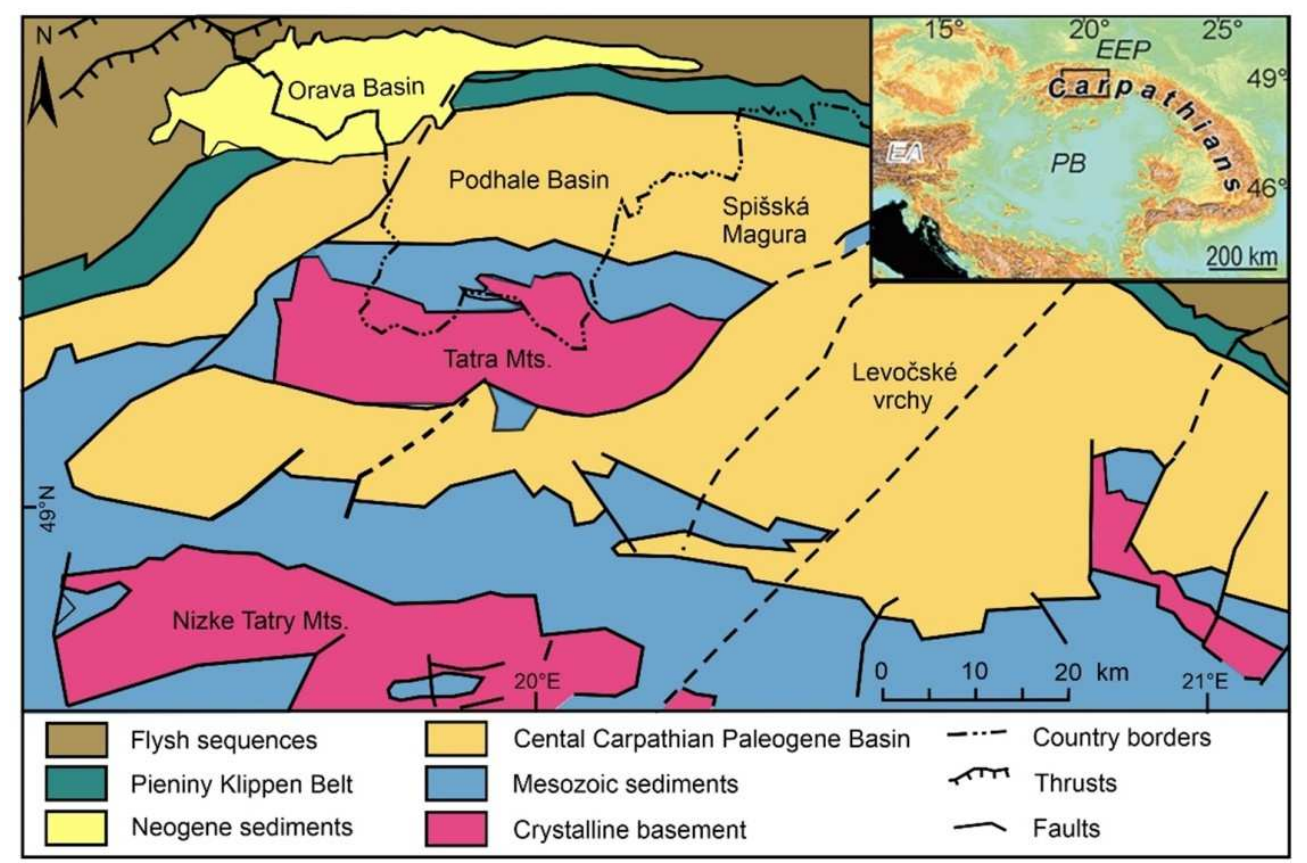

Fig. 1 Tectonic divisions of the Western Carpathians surrounding the Spisska Magura and Podhale regions (modified from Bezák, 2008)

The studied sites occur in the Bachledova Valley east of the village Ždiar in the Spišská Magura region and on the left side of the Dunajec riverbank between village Czarna Góra and Jurgów in Poland (Podhale region; Fig. 2).

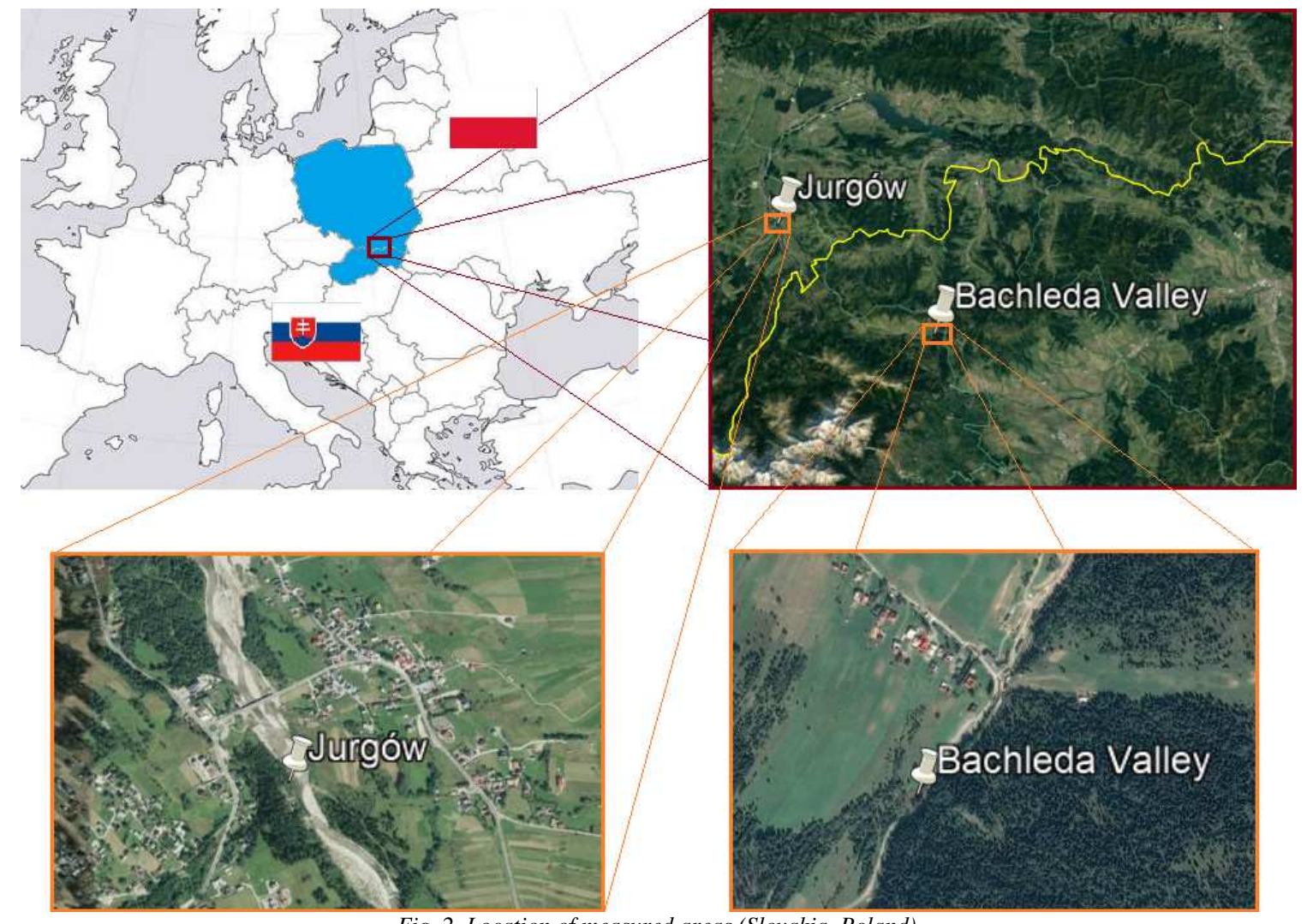

Fig. 2 Location of measured areas (Slovakia, Poland) 


\section{Methods}

Geodetic and photogrammetric measurements

For the detailed geometric documentation of individual outcrop sites, different surveying techniques and instruments have been used:

- Digital photogrammetry using the Structure-from-Motion algorithm has been used for mapping the outcrop's surface resulting in a 3D digital model and orthomosaic. Measurements were performed using the camera of the Mavic 2 Pro drone, and Pentax K-5 camera (Fig. 4). The image processing has been performed in Agisoft Metashape 1.5.0 software.

- Terrestrial laser scanning (TLS) was used similarly for a non-selective survey of outcrops resulting in a textured point cloud (Leica ScanStation C10 - Fig. 3 and Table 1).

- Total station and the spatial polar method were used for the control and check points measurements (Leica TS15).

- The coordinates of stations of these instruments were measured using a Leica GPS900CS GNSS receiver.

Tab. 1 Parameters of a terrestrial laser scanner Leica ScanStation C10

\begin{tabular}{|c|c|}
\hline \multicolumn{2}{|c|}{ Technical specification of the laser scanner } \\
\hline $\begin{array}{l}\text { Acc. of a single } \\
\text { measurement }\end{array}$ & \\
\hline $\begin{array}{c}\text { Position/Distance } \\
\text { Angle precision }\end{array}$ & $6 \mathrm{~mm} / 4 \mathrm{~mm}$ \\
\hline Horizontal/Vertical & $12^{\prime \prime} / 12^{\prime \prime}$ \\
\hline Modelled surface precision & $2 \mathrm{~mm}$ \\
\hline $\begin{array}{c}\text { Range } \\
\text { Minimal step of scanning }\end{array}$ & $\begin{array}{c}300 m @ 90 \% ; 134 m @ 18 \% \\
1 m m\end{array}$ \\
\hline Scan rate & $50000 / \mathrm{sec}$ \\
\hline Laser class & $3 R$, green $(\lambda=532 \mathrm{~nm})$ \\
\hline $\begin{array}{c}\text { Spot size } \\
\text { Field of view }\end{array}$ & $0-50 \mathrm{~m} \approx 4,5 \mathrm{~mm}$ \\
\hline Vertical/Horizontal & $270^{\circ} / 360^{\circ}$ \\
\hline
\end{tabular}

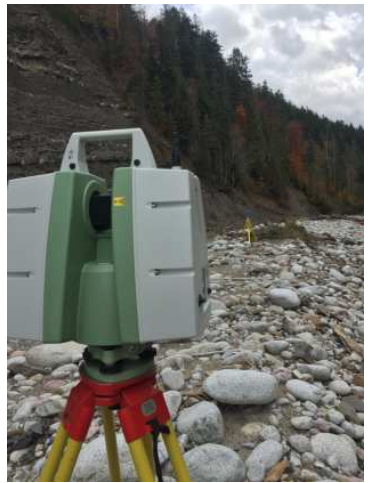

Fig. 3 Leica Scanstation C10 Scanner

\section{Surveying and processing workflow}

Aerial oblique images were acquired using a Hasselblad L1D-20c camera, which is the integrated camera of a Mavic 2 Pro RPAS (Tab. 2). Terrestrial images were taken using a Pentax K-5 camera with mounted lens Pentax SMC DA 15mm f/4 ED AL Limited (Tab. 2 and Fig. 4). Image acquisition was performed handheld, without external stabilization. Images from the RPAS were captured while the drone was hovering, with additional mechanical image stabilization (Fig. 4). Both image sets used specific ISO and shutter speed ideal for the given camera station.
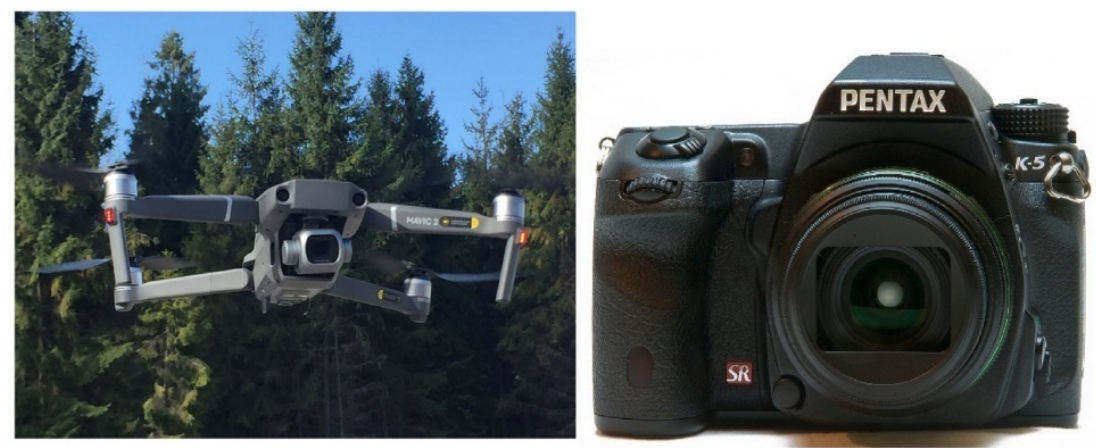

Fig. 4 RPAS system Mavic 2 Pro and DSLR Pentax K5

Tab. 2 Technical specifications of the used cameras

\begin{tabular}{|c|c|c|c|c|c|}
\hline Camera & $\begin{array}{c}\text { Sensor } \\
{[\mathrm{mm}]}\end{array}$ & $\begin{array}{c}\text { Pixel size } \\
{[\mu \mathrm{m}]}\end{array}$ & $\begin{array}{c}\text { Resolution } \\
\text { [pix] }\end{array}$ & $\begin{array}{c}\text { Focal length } \\
{[\mathrm{mm}]}\end{array}$ & Format \\
\hline Pentax K-5 & $23.6 \times 15.7$ & 4.77 & $3264 \times 4928$ & 15.0 & JPEG \\
\hline Hasselblad L1D-20c & $13.2 \times 8.8$ & 2.41 & $5472 \times 3648$ & 10.3 & JPEG \\
\hline
\end{tabular}


Images were processed in Agisoft Metashape software (Agisoft Metashape User Manual, 2019). The general workflow of the photogrammetric processing was as follows:

1. Importing images and coordinates of control points to Metashape.

2. Photo alignment - calculating the parameters of interior and exterior orientation.

3. Measurement of the control points on the images.

4. Georeferencing using Helmert transformation.

5. Generating a dense point cloud (Figs. 5, 6).

6. Generating a 3D polygonal (TIN) model.

7. Adjusting the brightness and contrast of images.

8. Projection of these images onto the mesh model and generating an orthomosaic (Figs. 7, 8)

9. Exporting orthomosaics with a suitable scale and the creation of 2D plans.

During measurements, a total station and a TLS were also used. The coordinates of stations of these instruments were determined using a Leica GPS900CS GNSS instrument in the coordinate system Datum of Uniform Trigonometrical Cadastral Network (Slovak: S-JTSK) in the realization UTCN03 (Slovak: JTSK03). The total station Leica TS15 (accuracy of distance measurement - any surface $2 \mathrm{~mm}+2 \mathrm{ppm}$, the accuracy of angular measurement 1") was used for measuring photogrammetric targets and naturally signalized high-contrast points. These points were later used for georeferencing of the photogrammetric model. The estimated accuracy of control points (according to used instruments and methods) is $m_{x y}=15 \mathrm{~mm}$ and $m_{z}=25 \mathrm{~mm}$. TLS surveys were also performed on each site. We used a direct georeferencing method, where the scanner was set up over a known point (and its height over the point measured by GNSS), centred, levelled and oriented towards another known target (backsight) (Reshetyuk, 2009). The position and orientation information and the instrument height were entered into the scanner software before the scanning.

The immediate result of scanning was a dense point cloud. When processing point clouds, textures were also projected onto the point cloud from TLS. Unwanted points were deleted. It must be stated that for the Bachledova valley outcrop, the internal camera of the scanner was not used due to very bad light conditions.

\section{Geological measurements}

Observations were made on two sites located in the Spišská Magura region in Slovakia and in the Podhale region in Poland. We performed the structural analysis by conventional geological methods to determine the primary sedimentary structures (plane bedding) and the secondary structures represented by faults and joints. The collected data were processed and visualized using the structural geology software TectonicsFP and subsequently projected on the orthomosaics acquired from photogrammetric measurements.

\section{Results}

In this paper, two problems were explored - the accuracy of photogrammetric models (depending on the position of the photo camera - terrestrial and aerial) and the contribution of the model to geological interpretation. The sufficiency of a lower amount of control points would mean sparing temporal and financial expenses. Geological evaluation of results can estimate the pros and cons of geodetic documentation and suggest some improvements for future work.

\section{Influence of number and location of control points on accuracy}

\section{Bachledova valley}

In the field, 3 survey stations were monumented as temporary points with the aim of having sufficient overlap for the TLS measurement. The outcrop was documented using terrestrial digital photogrammetry with the Pentax K-5 camera capturing 100 images with the Ground Sample Distance (GSD) of $3 \mathrm{~mm} / \mathrm{pix}$. The photogrammetric imaging was realized using a tripod and $12 \mathrm{sec}$ self-timer from an average imaging distance of $10 \mathrm{~m}$. As ground control points (either control or check points), coordinates of 4 naturally targeted points were adopted from the point cloud obtained by terrestrial laser scanning (Fig. 5). In this case, all 4 points were used as ground control points; the residuals and the RMSE (root-mean-square error) are given in Table 3. Due to the smaller size of the outcrop, only terrestrial images were captured.

\section{Jurgów}

In the field, four stations were stabilized to have sufficient overlap for the TLS measurement and measure key points using the total station. On the side of the outcrop, 4 circular coded photogrammetric markers were temporarily marked and were measured using the total station. Additionally, 10 naturally targeted ground control points were measured. The outcrop was documented by using a combination of RPAS and terrestrial digital photogrammetry with the integrated Hasselblad L1D-20c camera of a Mavic 2 Pro RPAS capturing 82 images 
and a Pentax K-5 camera capturing 98 images with the GSD of $5.72 \mathrm{~mm} /$ pix. The terrestrial photogrammetric imaging was realized using a tripod and $12 \mathrm{sec}$ self-timer. The common imaging was realized from an average imaging distance of $34 \mathrm{~m}$. The placement of markers is shown in Fig. 6. The values of residuals are in Tab. 4.

Tab. 1 Residuals and RMSE of GCPs for both outcrops

\begin{tabular}{c|ccccc} 
Outcrop & $\begin{array}{c}\text { X error } \\
{[\mathrm{mm}]}\end{array}$ & $\begin{array}{c}\text { Y error } \\
{[\mathrm{mm}]}\end{array}$ & $\begin{array}{c}\text { Z error } \\
{[\mathrm{mm}]}\end{array}$ & $\begin{array}{c}\text { RMSE } \\
{[\mathrm{mm}]}\end{array}$ & $\begin{array}{c}\text { RMSE } \\
{[\mathrm{pix}]}\end{array}$ \\
\hline $\begin{array}{c}\text { Bachledova } \\
4 \text { GCP }\end{array}$ & 11 & 12 & 14 & 21 & 1.26 \\
$\begin{array}{c}\text { Jurgów } \\
\text { 14 GCP }\end{array}$ & 8 & 12 & 10 & 18 & 0.79
\end{tabular}

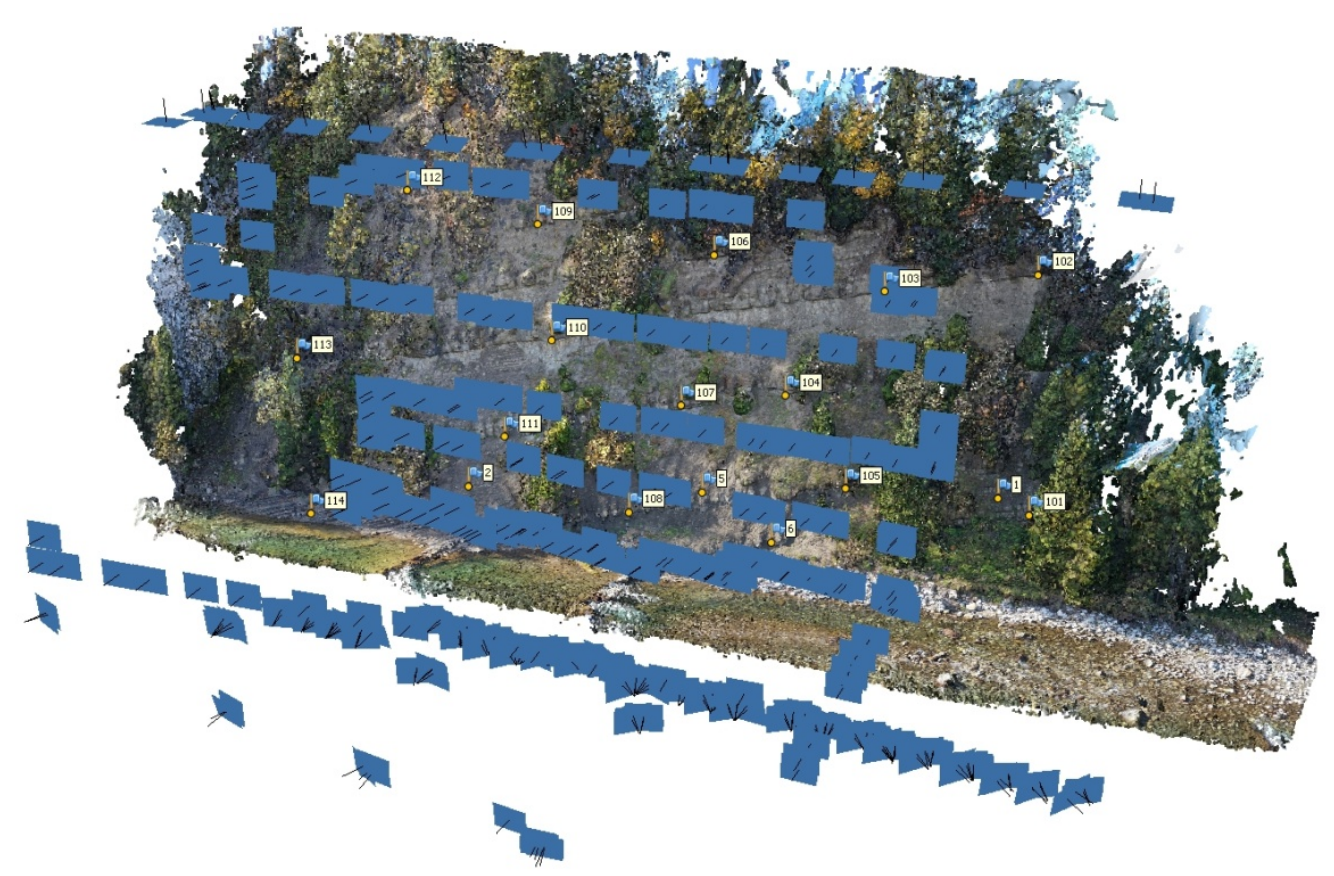

Fig. 5 Ground control points in Jurgów and the camera capture positions

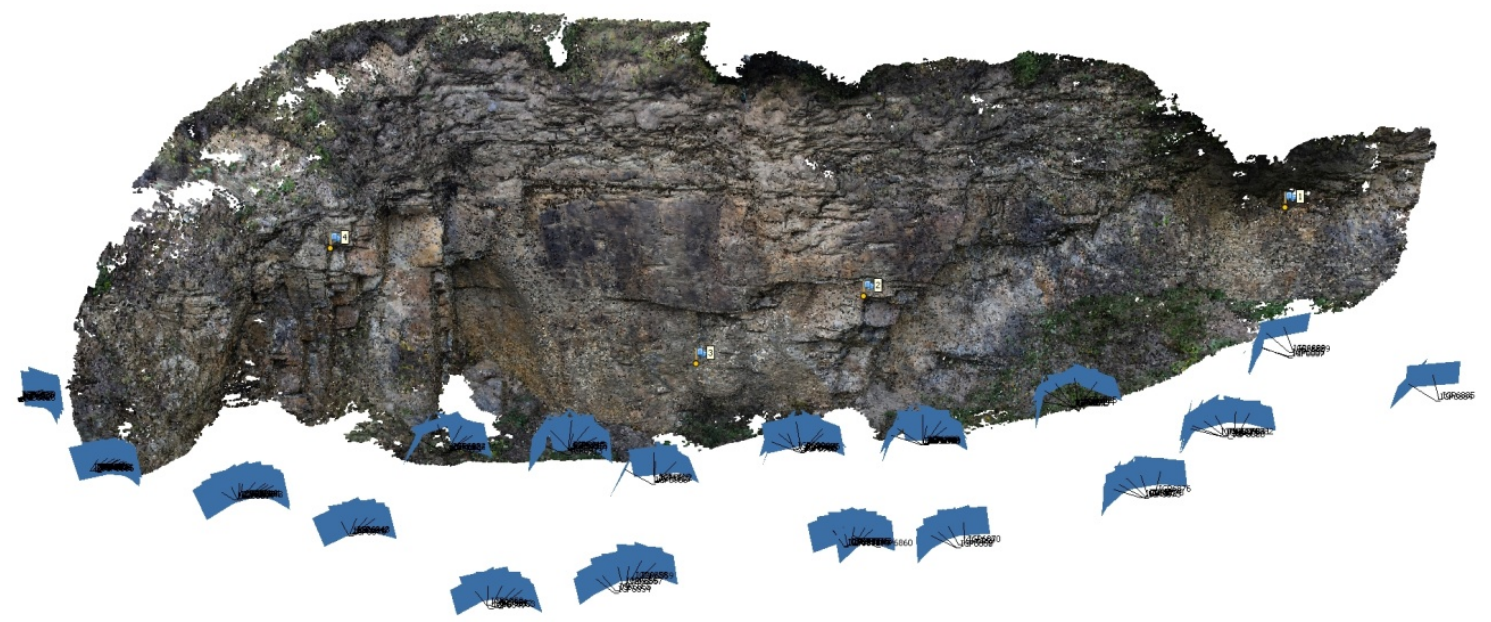

Fig. 6 Ground control points in Bachledova valley and the camera capture positions

According to the residuals, when every marker is used for georeferencing, there are no outliers among the control points. It is important to note that the mean square value of the reprojection error is 0.79 pixels thanks to the RPAS systems ability to capture images from distances and angles that are impossible to achieve from ground level; thus, the placement of markers in the image plane is far more accurate. The RMSE of $18 \mathrm{~mm}$ is sufficient for such geological applications. 
Tab. 4 Control point and Check point residuals of different configurations (red points were used as control points, black as check points)

\begin{tabular}{c|cccccccccccccccc}
$\begin{array}{c}\text { RMSE } \\
\text { [mm] }\end{array}$ & 1 & 2 & 5 & 6 & 101 & 102 & 103 & 104 & 106 & 107 & 108 & 109 & 110 & 111 & $\begin{array}{c}\text { Control } \\
\text { points }\end{array}$ & $\begin{array}{c}\text { Check } \\
\text { points }\end{array}$ \\
\hline Var. 1 & 23 & 37 & 10 & 16 & 15 & 18 & 14 & 12 & 19 & 10 & 7 & 23 & 7 & 19 & 18 & NA \\
Var. 2 & 24 & 29 & 18 & 30 & 27 & 12 & 17 & 21 & 23 & 16 & 14 & 26 & 13 & 15 & 24 & 20 \\
Var. 3 & 23 & 31 & 15 & 25 & 24 & 14 & 14 & 16 & 21 & 13 & 11 & 25 & 12 & 14 & 23 & 17
\end{tabular}

The results of testing different configurations of control and check points indicate that just as in the previous case, no statistically significant difference in the values of residuals could be observed between var. 2 and var. 3 on point 104, var. 1 still produced results with the least mean square values.

\section{Graphical results}

One of the basic outputs of photogrammetric image processing is an orthomosaic of the mapped surface outcrop in our case. As defined in photogrammetric terminology, an orthoimage is represented by a differentially rectified image (perspective transformation to an orthographic), correcting for most distortions (Granshaw, 2016). For both mapped outcrops, the final ortohomosaics were generated with the Ground Sample Distance of 7mm/pix (Bachledova valley - Fig. 7), and 10mm/pix (Jurgów - Fig. 8). These were then used for a geological interpretation of morphological structures - see chap. Discussion - Geological interpretation.
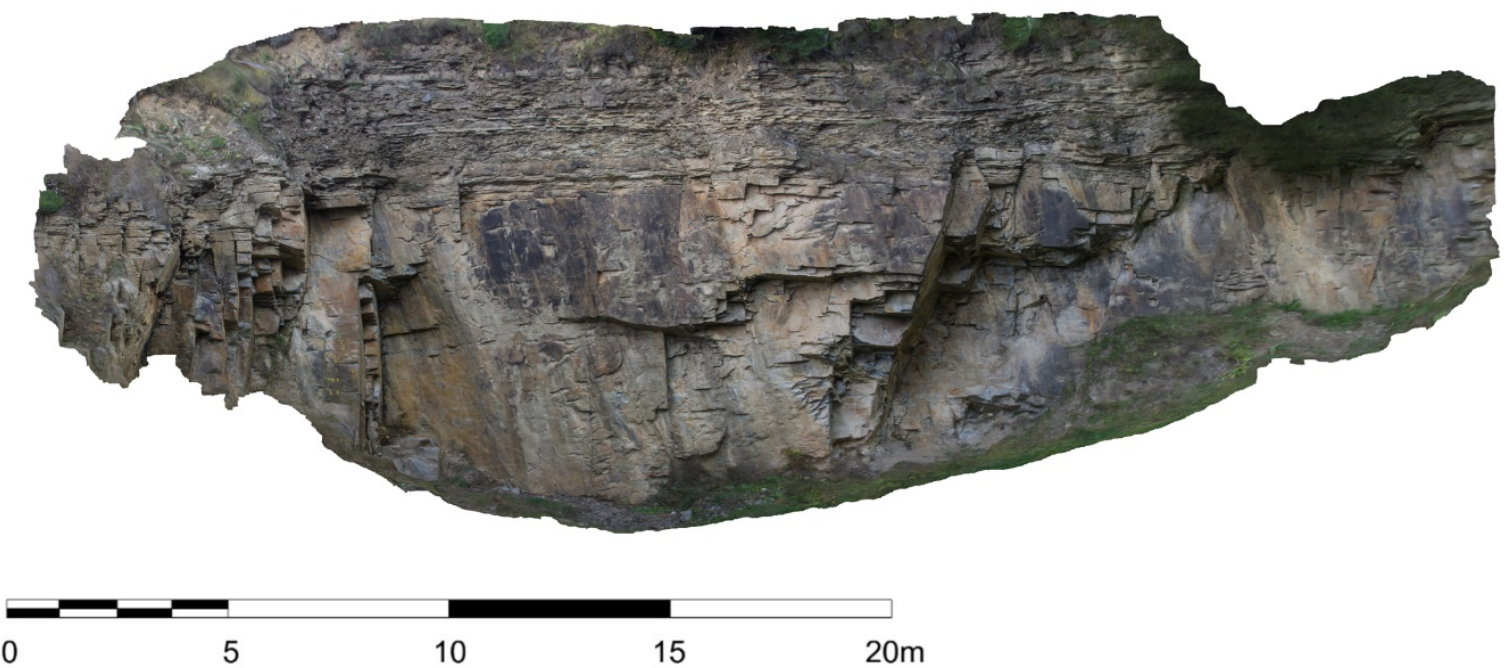

Fig. 7 Orthomosaic of the outcrop in Bachledova valley

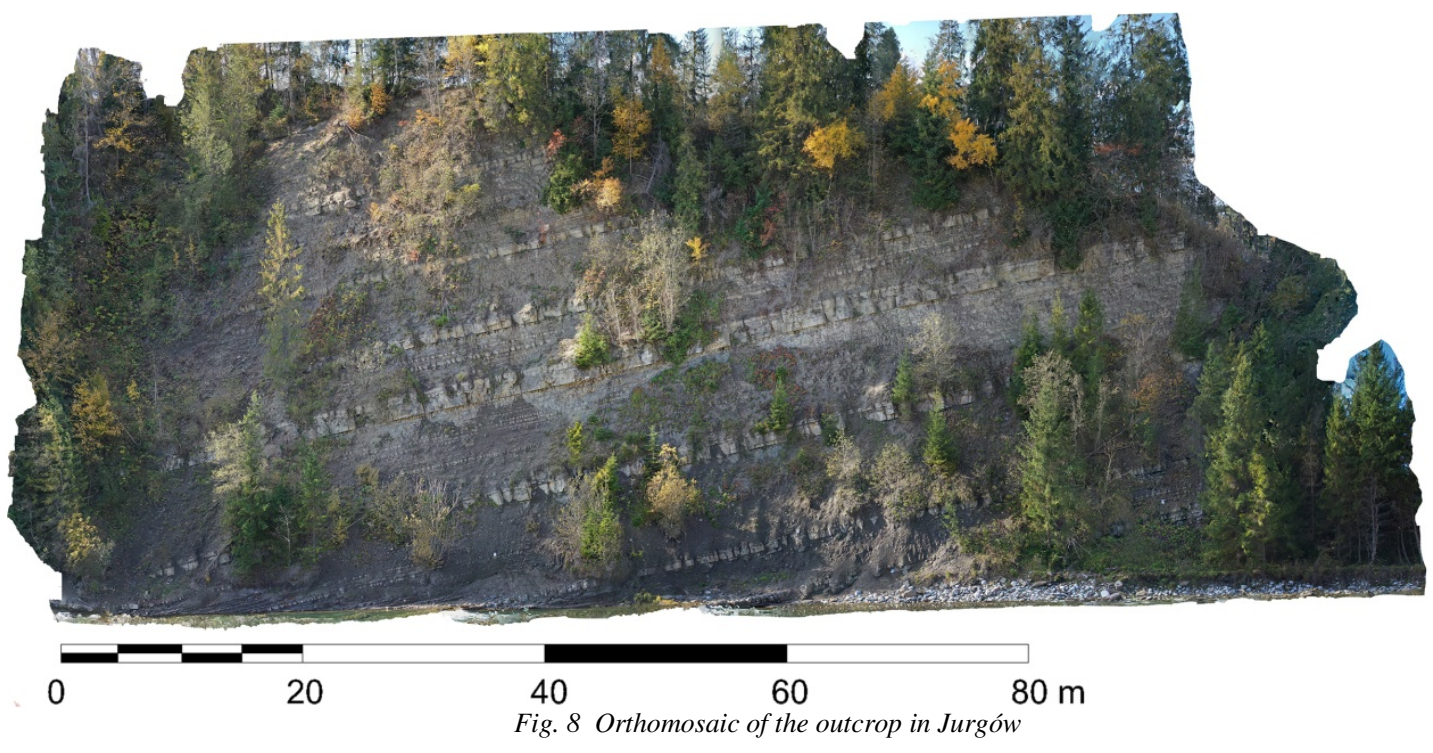




\section{Discussion}

\section{Analysis of results from TLS and Photogrammetry}

The basic analysis and comparison of the results obtained by geodetic survey using TLS and digital photogrammetry were carried out based on a difference models between individual point clouds. For the Bachledova valley site, only the results from TLS vs terrestrial photogrammetry were compared. For the Jurgów site, the point cloud from TLS was compared against the point cloud created by a combined photogrammetric image processing of RPAS and terrestrial images. All difference models with corresponding graphical representations were created in CloudCompare 2.10 software using the Multiscale Model to Model Cloud Comparison "M3C2 distance" plugin (Lague et al., 2013), which allows determining robust signed distances directly between two point clouds.

\section{Bachledova valley}

A difference model for the outcrop in Bachledova valley was derived from the comparison of TLS point clouds vs terrestrial photogrammetry point cloud (Fig. 9). The deviations range in the interval <-50mm, $+50 \mathrm{~mm}>$, with the mean value of $8 \mathrm{~mm}$. The highest deviations can be observed in the marginal parts of the model, corresponding to the vegetation around the outcrop. The rocky parts of the outcrop show minimal deviations.

The frequency histogram of deviations (Fig. 10) has a normal distribution represented by the Gaussian curve, with one peak, however, with a negative shift between point clouds of $-8 \mathrm{~mm}$. This can be attributed to a minimum reduction of the compared data against the reference data. Similar values of the negative shift were obtained for the second outcrop in Jurgów; however, in this case, it represents a more significant deviation as the imaging distance was 3 times shorter $(10 \mathrm{~m}$ vs $34 \mathrm{~m})$. Such a reduction of the photogrammetry data can be attributed to the fact that ground control points for a photogrammetry model georeferencing were realized only as 4 naturally target distinctive features on the rock surface (corners, notches) and no artificial surveying marks (for example, coded targets) were used.

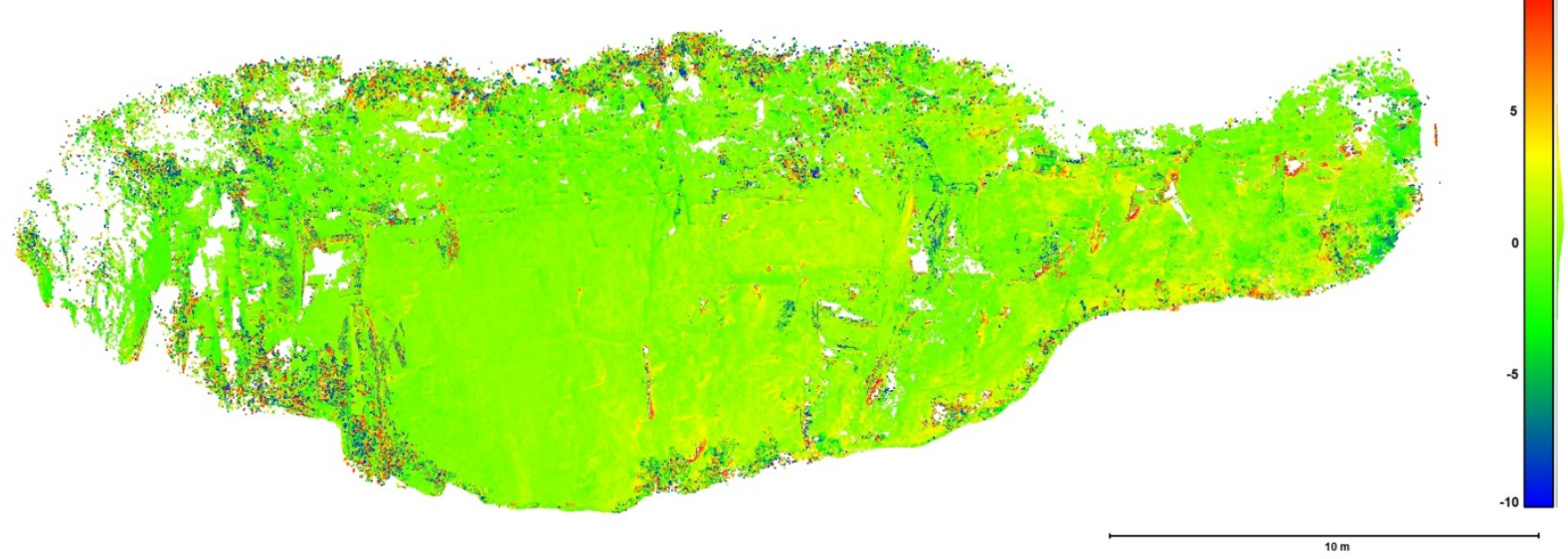

Fig. 9 Difference model between two point clouds (TLS and terrestrial photogrammetry) for Bachledova valley
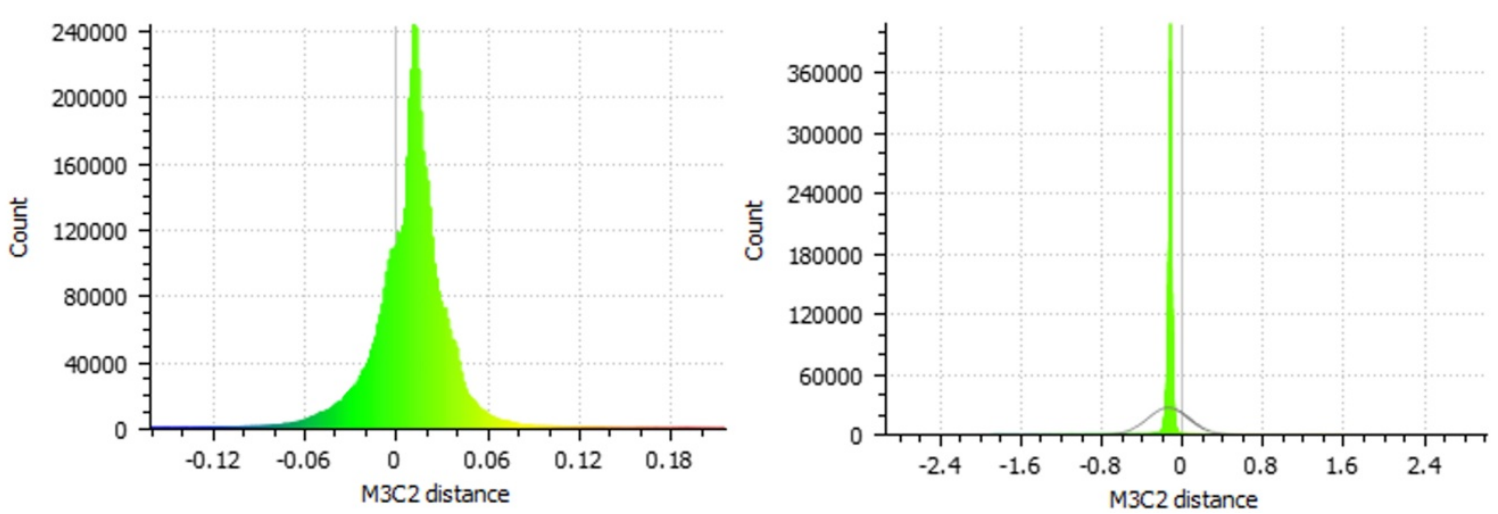

Fig. 10 Graphical analysis of the frequency distribution and deviations from the normal distribution for Bachledova valley 


\section{Jurgów}

For the outcrop in Jurgów, the difference model between TLS data and data from the combined photogrammetric processing (RPAS + terrestrial photogrammetry) shows smaller deviations within the interval $<-70 \mathrm{~mm},+70 \mathrm{~mm}>$ and the mean value of deviations $23 \mathrm{~mm}$ (Fig. 12). The most significant deviations (approx. $100 \mathrm{~mm}$ ) can be observed in the areas covered with vegetation, which was expected since these parts of the outcrops are relatively densely overgrown, and the imaging was carried out in relatively windy weather. Additionally, more significant deviations were observed in the model's left edge (from green to blue) (Fig. 11). On the one hand, this part is the most densely covered with vegetation, and on the other hand, the least covered with ground control points (see Fig. 4), which could have caused a distortion of the model in this part.

The graphical distribution of deviations corresponds to the normal distribution with sharp edges and one peak. However, there is also present a negative shift of $-6 \mathrm{~mm}$, representing a minor reduction of the compared model as in the previous case. This is, however, a negligible value regarding the accuracy achieved by combining RPAS and terrestrial photogrammetry.

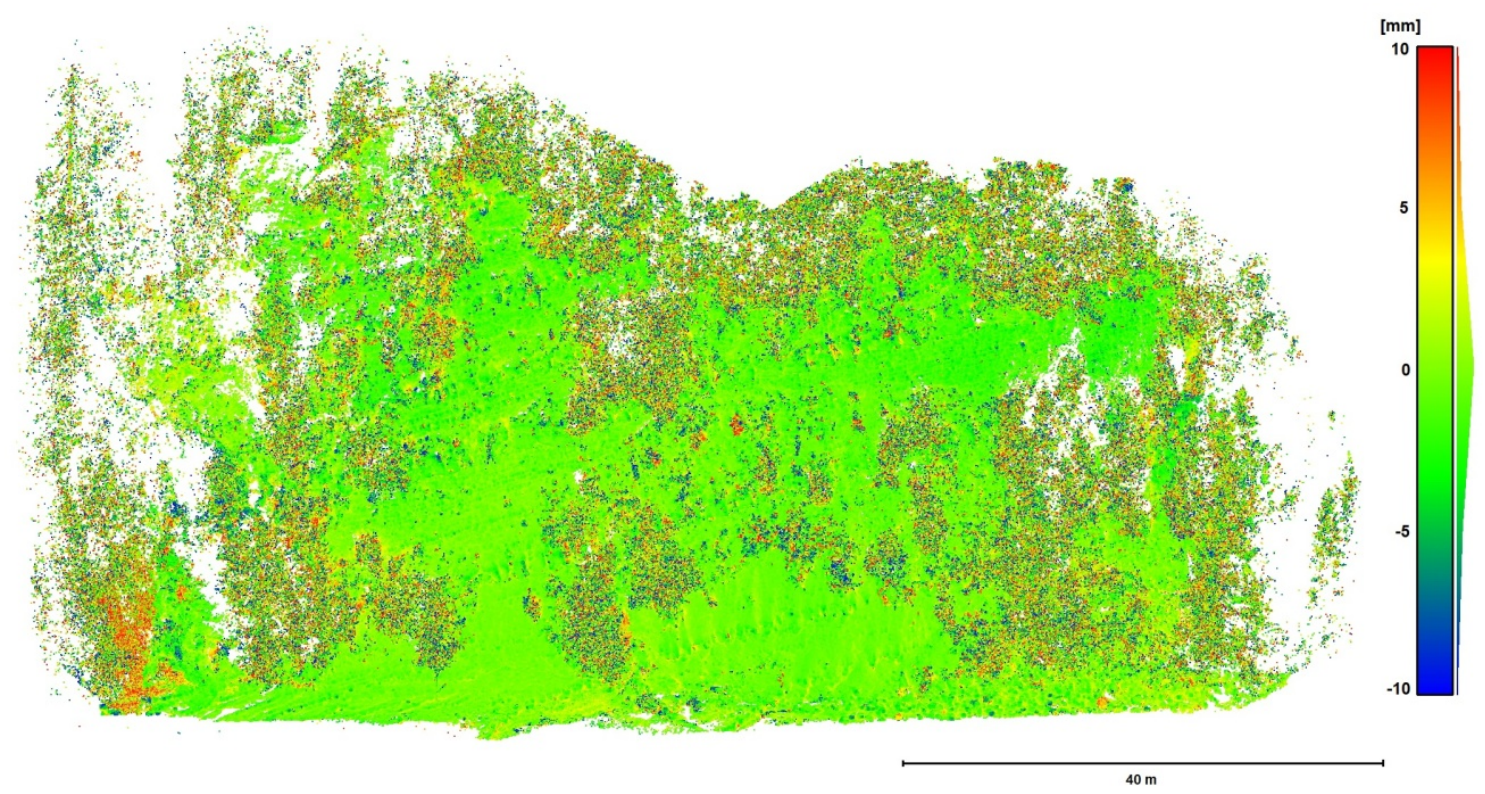

Fig. 11 Difference model between two point clouds (TLS and combined RPAS and terrestrial photogrammetry) for Jurgów
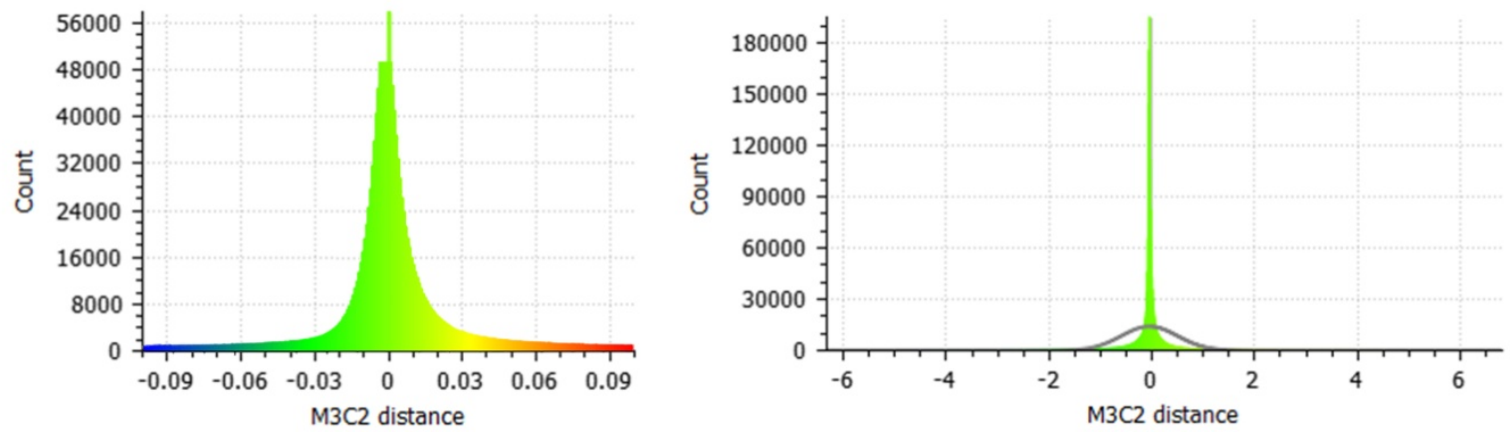

Fig. 12 Graphical analysis of the frequency distribution and deviations from the normal distribution for Jurgów

\section{Surveying interpretation}

TLS technology represents a fast and accurate method of non-contact data collection also for the needs of geological mapping of inaccessible morphological structure. However, its main disadvantage is significantly higher financial costs. Moreover, in some cases, it may not be possible to use the instrument's integrated camera to record the RGB texture of the measured surface, which results in the loss of important data. Therefore generating textural outputs, for example, orthomosaics is impossible; thus, no geological interpretation can be performed. We encountered this problem during the survey of the outcrop in Bachleda valley, as difficult lighting conditions did not allow us to use the integrated digital camera of the TLS (i.e. it would not be practical). Based on a test imaging of the outcrop, we evaluated the texture quality as maximally insufficient. 
On the other hand, modern technologies in digital photogrammetry provide cheap, fast, and accurate survey, even in such hardly accessible outcrops. Depending on the camera and equipment used (tripod, self-timer, type of the camera and lens, etc.), it is possible to capture high-quality images even in poor lighting conditions and thus obtain data of the same quality (in terms of spatial accuracy) as when using TLS. This was confirmed by comparing such data in the previous chapter for Bachledova valley. In addition, when using RPAS technology and a camera of satisfactory quality, we can extend the photogrammetric imaging by aerial imaging and thus get a view of the parts of the outcrop that are partially or even completely obscured from ground camera stations.

Based on the previous results, we can say that the combination of terrestrial and RPAS photogrammetry can result in similar quality and accuracy outputs as terrestrial laser scanning, moreover with lower financial demands and a photo-texture with higher resolution. In photogrammetry, however, it is necessary to consider the use of artificial targets and precisely measured ground control points if high-quality results are required. This may not be feasible in the case of inaccessible outcrops or hardly accessible terrain; therefore, it is then necessary to find and use sufficiently high-contrast natural targets directly on the mapped structure. Since such points cannot provide the consistency of coded targets, it is important to take into account the possibility of lower resultant accuracy of the outputs.

\section{Geological interpretation}

\section{Bachledova valley}

The first study site is located in the open sandstone pit in the Bachleda valley (Fig. 1). The massive and faintly laminated sandstone is up to $7 \mathrm{~m}$ thick, is separated from the underlying mudstone of the Huty Fm. by a sharp boundary. The upper boundary is transitional with a fining-upward trend to the overlying mudstones of the same formation is intensively tectonically deformed, resulting in several structurally restricted blocks (Fig. 14). The bedding of the sandstone varies from $355-8^{\circ} / 20-26^{\circ}$ (Fig. 13, Table 5 and 6).

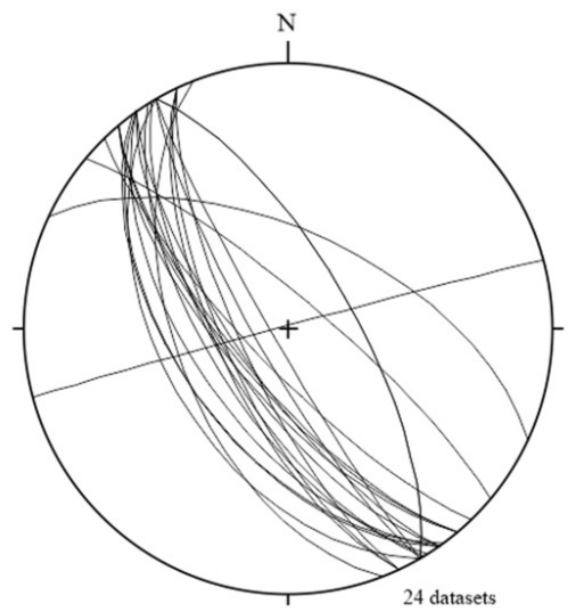

Fig. 13 Bedding position and orientation of tectonic structures in Bachledova valley

Tab. 5 Bedding position and orientation in Bachledova valley

\begin{tabular}{c|ccccc} 
Bedding & B1 & B2 & B3 & B4 & B5 \\
\hline Dip direction $\left[{ }^{\circ}\right.$ ] & 8 & 8 & 15 & 9 & 355 \\
Dip $\left[{ }^{\circ}{ }^{-}\right.$ & 22 & 25 & 24 & 26 & 20
\end{tabular}

\begin{tabular}{|c|c|c|c|c|c|c|c|c|c|c|c|c|}
\hline \multirow[b]{2}{*}{ Dip direction $\left[{ }^{\circ}\right]$} & \multicolumn{12}{|c|}{ Tectonic Structures } \\
\hline & 235 & 235 & 245 & 245 & 239 & 230 & 230 & 60 & 345 & 235 & 235 & 40 \\
\hline $\operatorname{Dip}\left[{ }^{\circ}\right]$ & 60 & 55 & 75 & 70 & 68 & 72 & 70 & 70 & 89 & 70 & 74 & 80 \\
\hline Dip direction $\left[{ }^{\circ}\right]$ & 240 & 230 & 249 & 240 & 245 & 240 & 238 & 240 & 234 & 226 & 60 & 25 \\
\hline $\operatorname{Dip}\left[{ }^{\circ}\right]$ & 80 & 73 & 55 & 85 & 68 & 50 & 65 & 80 & 55 & 78 & 70 & 60 \\
\hline
\end{tabular}


Based on our measurements, we recognized two groups of fractures:

1. Extensional tectonic structures with orientations NW-SE, dipping 60-85

2. Tectonic structures with ENE-WSW direction resulted from NNW-SSE extension (Fig. 14).

According to geometry and correlation of tectonic structures in the Bachleda sandstones, we observed crosscutting faults, which produce the characteristic X in cross-section (Fig. 14). These types of faults are generally termed conjugate faults or "hourglass" structures and are interpreted as resulting from strike-slip movement (e.g. Thatcher and Hill, 1991).

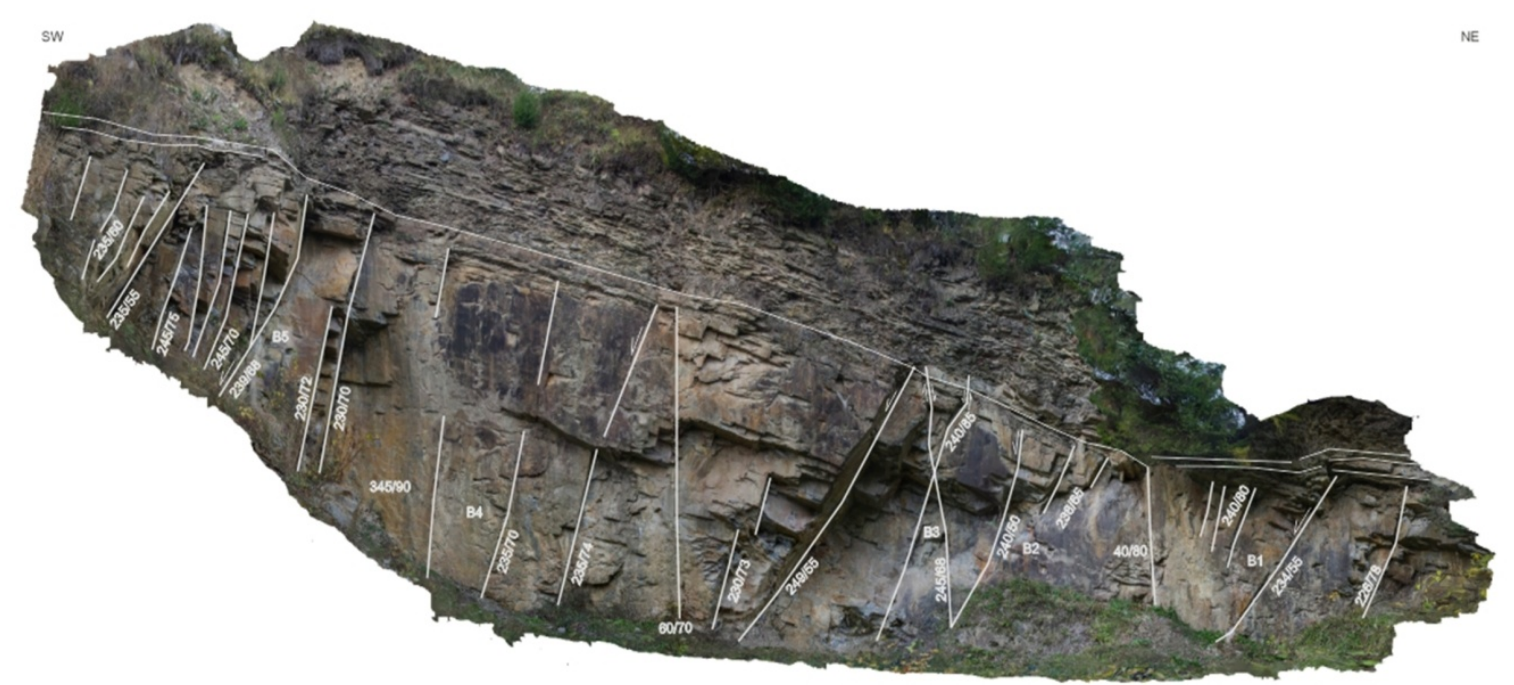

Fig. 14 Sketch of the outcrop in Bachledova valley drawn into the orthomosaic

\section{Jurgów}

The outcrop on the left side of the Bialka river near the Jurgów village is approximately $46 \mathrm{~m}$ high; therefore, it belongs to hardly accessible locality in the aspect of collecting geological data.

This outcrop is represented by the Oligocene Zuberec Fm. (Chocholow Beds in Poland) of deep-water origin. The sediments consist of grey mudstone alternating with fine to medium-grained sandstone. The sandstone is massive, parallelly laminated and ripple cross-laminated. They form both thin (up to $100 \mathrm{~mm}$ thick) beds intermittently occurring in the mudstone and thick beds organized in up to $6 \mathrm{~m}$ thick sandstone intervals. There are 6 such intervals in the entire outcrop profile (Fig. 15).

Dominating bedding strikes are $130-145^{\circ}$, and dips are ranging from $5-20^{\circ}$ (Fig. 16, Table 7 and 8 ). Locally, the dip direction is $45^{\circ}$ (Fig. 15).

According to the structural analysis, dominant tectonic structures with N-S, NW-SE, ENE-WSW, and NESW direction were observed (Fig. 14).

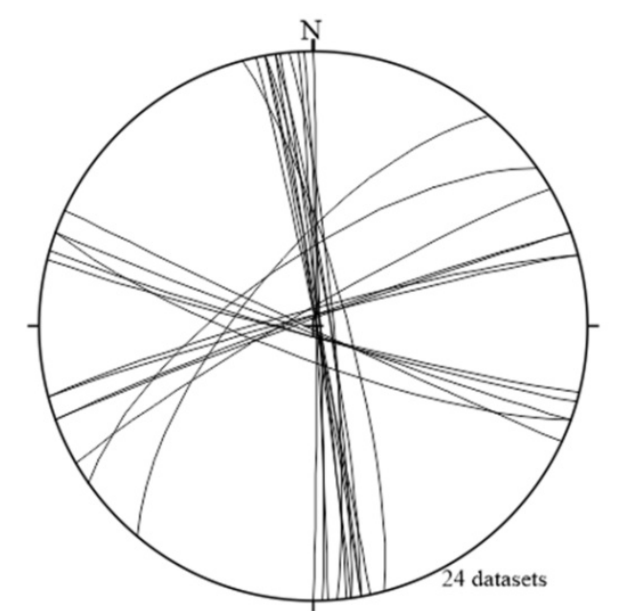

Fig. 3 Bedding position and orientation of tectonic structures in Jurgów
Tab. 7 Bedding position and orientation in Jurgów

\begin{tabular}{c|ccccc} 
Bedding & B6 & B7 & B8 & B9 & B10 \\
\hline $\begin{array}{c}\text { Dip } \\
\text { direction [ }{ }^{\circ} \text { ] }\end{array}$ & 135 & 130 & 175 & 145 & 140 \\
Dip [ ${ }^{\circ}$ ] & 10 & 15 & 5 & 15 & 15 \\
\hline Bedding & B11 & B12 & B13 & B14 & B15 \\
$\begin{array}{c}\text { Dip } \\
\text { direction [ }{ }^{\circ} \text { ] }\end{array}$ & 157 & 145 & 345 & 265 & 358 \\
Dip [ ${ }^{\circ}{ }^{-}$ & 5 & 15 & 15 & 20 & 48
\end{tabular}




\begin{tabular}{|c|c|c|c|c|c|c|c|c|c|c|c|c|}
\hline \multirow[b]{2}{*}{ Dip direction $\left[{ }^{\circ}\right]$} & \multicolumn{12}{|c|}{ Tectonic Structures } \\
\hline & 82 & 80 & 82 & 90 & 200 & 196 & 205 & 83 & 80 & 80 & 78 & 345 \\
\hline Dip $\left[{ }^{\circ}\right]$ & 85 & 85 & 89 & 89 & 88 & 87 & 89 & 88 & 88 & 89 & 89 & 85 \\
\hline Dip direction $\left[{ }^{\circ}\right]$ & 87 & 340 & 85 & 88 & 345 & 330 & 200 & 75 & 310 & 325 & 340 & 194 \\
\hline Dip $\left[{ }^{\circ}\right]$ & 89 & 88 & 84 & 88 & 87 & 85 & 80 & 80 & 70 & 70 & 87 & 87 \\
\hline
\end{tabular}

Based on geometry and orientation, we classified tectonic structures into 4 groups:

1. Joint system consisting of the parallel joints with N-S direction and joints with NW-SE direction (Fig. 16, A).

2. System of calcite-filled parallel fractures with orientation N-S and NE-SW to ENE-WSW direction (Fig. 16, B).

3. Mesoscale fractures in intervals of alternating mudstones and sandstones with NNW-SSE direction (Fig. 16, C).

4. Normal fault (probably with strike slip component) with NW-SE direction (Fig. 17 and Fig. 18).
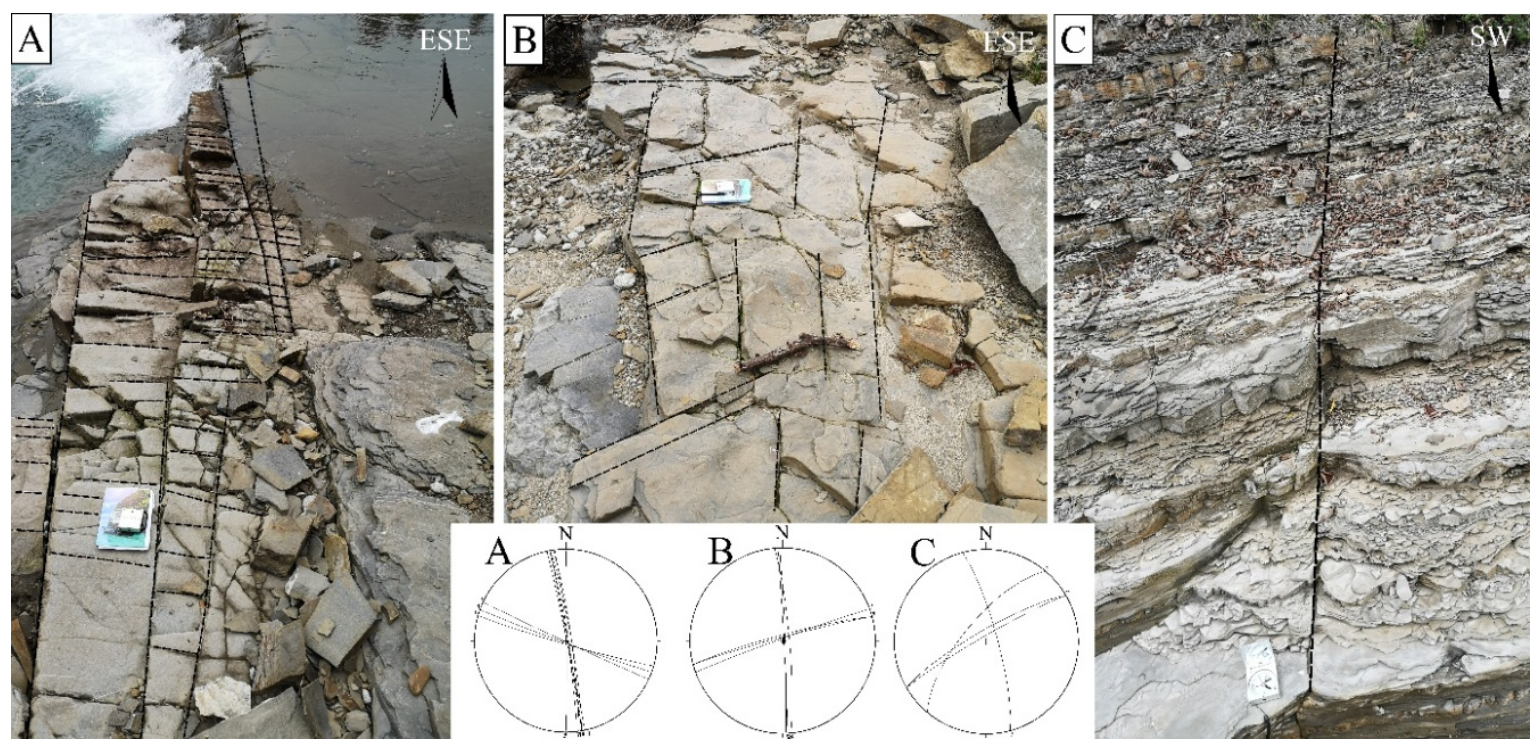

Fig. 16 Systems of observed fractures in Jurgów

We identified a normal fault which is observable due to different dip and dip direction around the fault (Fig. 17 and Table 9) and by the direct observation of sandstone intervals at the left and right side of the outcrop. Fig. 18 illustrates a normal fault with NW-SE direction related to NE-SW extension, which caused subsidence of the right side of the outcrop. Observation from a greater distance helped to identify this type of tectonic structure. 

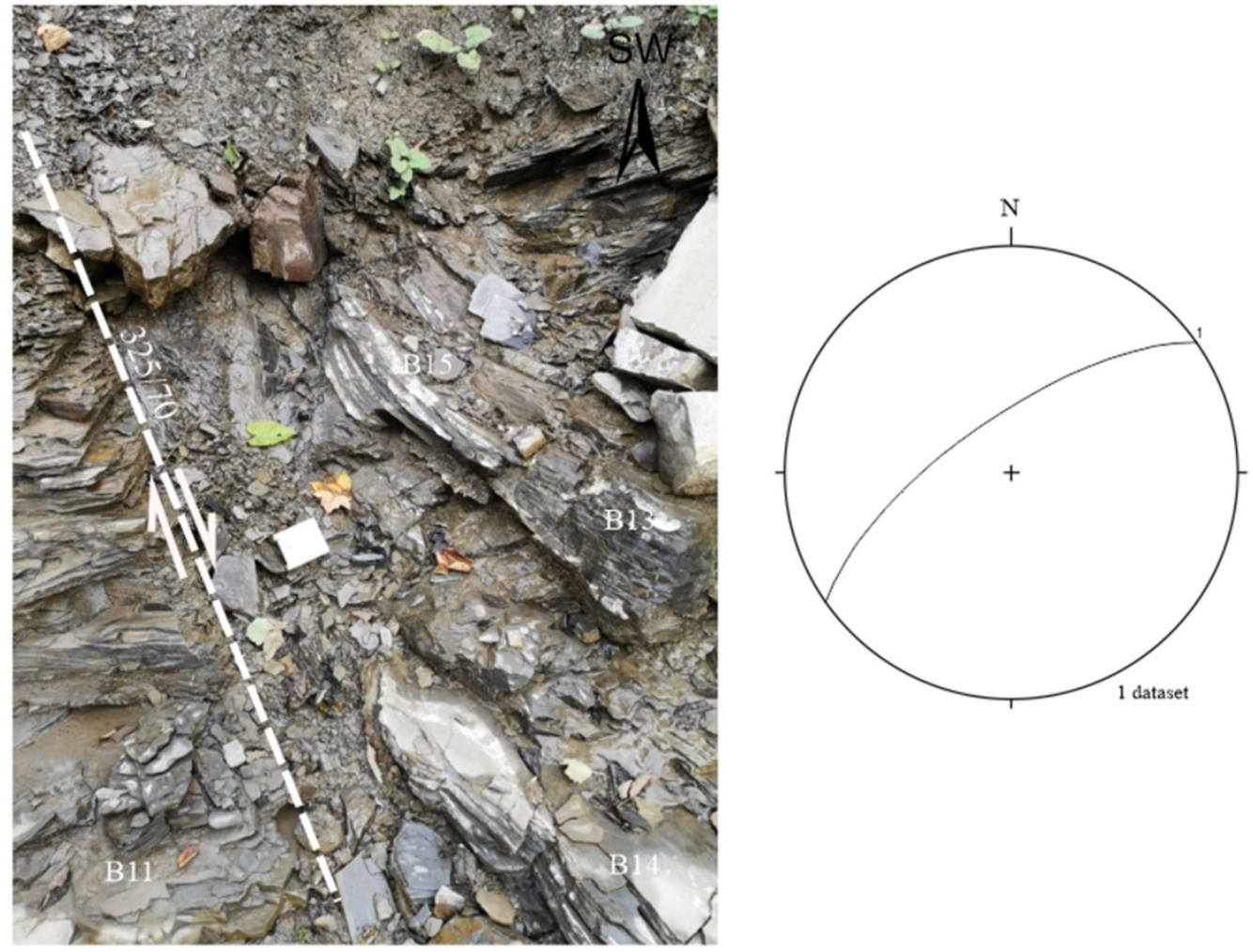

Fig. 17 Field observation of normal faulting in Jurgów

Tab. 9 Bedding position and orientation in Jurgów

\begin{tabular}{c|cccc} 
Bedding & B11 & B13 & B14 & B15 \\
\hline Dip direction $\left[{ }^{\circ}\right.$ ] & 157 & 345 & 265 & 358 \\
Dip [ ${ }^{\circ}$ ] & 5 & 15 & 20 & 45
\end{tabular}

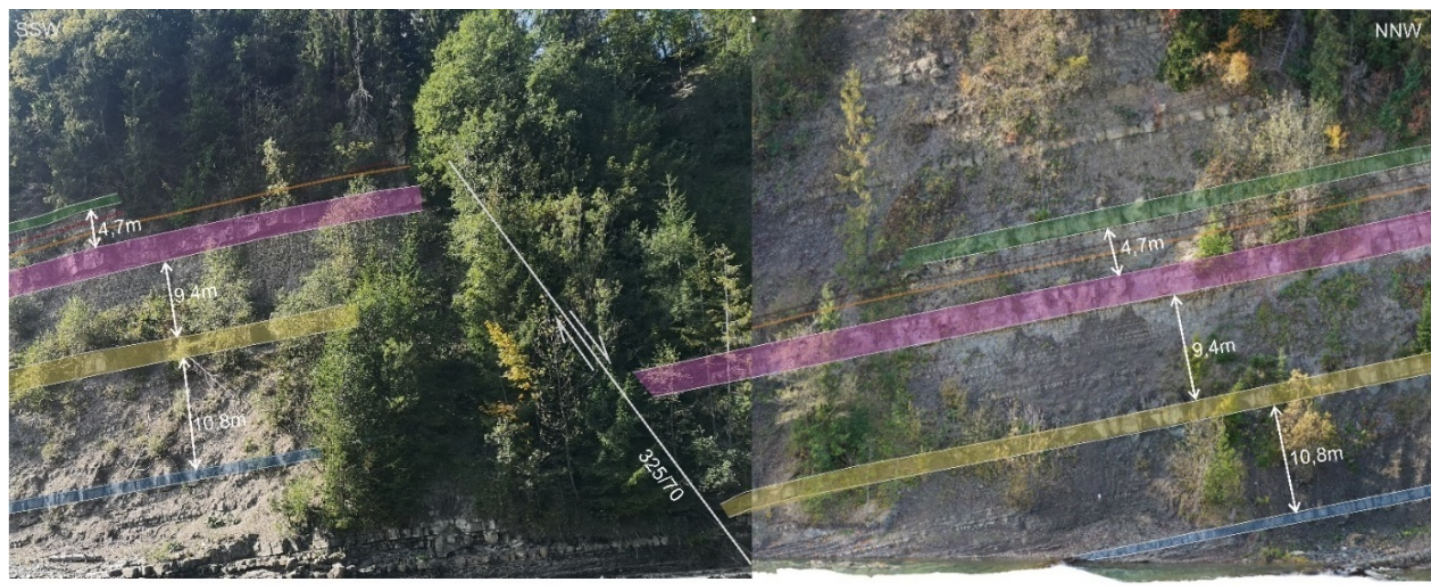

Fig. 18 Sketch of the outcrop in Jurgów

\section{Conclusion}

Close-range digital photogrammetry using the combination of an RPAS system and a DSLR camera mounted on a tripod performed well in the given conditions. The structure and texture of the measured objects were various enough to enable the processing of the images using the general workflow of the SfM algorithm. The acquired mean square values of residuals of $21 \mathrm{~mm}$ and $18 \mathrm{~mm}$ respectively when using all control points represent an accuracy that is sufficient for the production of an accurate and high-resolution orthomosaic, which is then suitable for such geological measurements. The results of photogrammetric image processing can be enhanced by optimizing the camera configuration, the placement of markers, and performing a bundle adjustment to minimise the residual on control points. Also, more accurate results can be achieved by using 
ground control points in the form of artificial coded targets, whose centres can be automatically determined with sub-pixel accuracy. However, in cases of such hardly accessible outcrops (Jurgów), or if other conditions do not allow to use of artificial targets (Bachledova valley), it is enough to measure a minimum necessary control points on the edges of the object and use natural points of the surface as ground control points. A further enhancement would be combining the acquired range data of the TLS system with the high-resolution outputs of photogrammetry. This would be justifiable, as both technologies can provide similar quality and accuracy of results, even for various imaging distances, as we proved for these two locations/outcrops. Overall, the use of non-contact surveying technologies of the selected outcrops was successful.

In the results, we have presented the photogrammetric method combined with geological structural analysis to detect tectonic structures in large-scale geological outcrops. The results of photogrammetry were used by geologists to interpret the geological situation in the outcrop in Bachledowa valley and in the outcrop near Jurgów village. The presence of geological structures was identified in the orthomosaic and supplemented with geological measurements only in such parts of outcrops that were accessible for geologists. For this reason, the combination of geological methods and non-contact surveying technologies appear to be a progressive solution in Structural geology. This method's advantage is the speed of the obtained data, efficiency, accuracy, ability to continue to work and receive new information in the office environment. An interesting extension of the issue would be the joint processing of the point clouds acquired from photogrammetry and TLS.

\section{References}

Agisoft.com. Online. [cit. 4.3. 2020] 〈https://www.agisoft.com/pdf/metashape-pro_1_5_en.pdf〉

Anczkiewicz, A., Środoń, J.and Zattin, M. (2013). Thermal history of the Podhale Basin in the internal Western Carpathians from the perspective of apatite fission track analyses. Geologica Carpathica, 64, 2, 141-151.

Bezák, V., Fritzman, R., Dzurenda, Š., Nováčková, M., DVOŘÁK, J. (2008): Prehl’adná geologická mapa Slovenskej republiky 1:200 000. Bratislava: Ministerstvo životného prostredia Slovenskej republiky, 2008.

Bistacchi A., Balsamo, F., Mozafari, S. M., Swennen, R., Solum, J., Tueckmantel, C., Taberner, C. (2015). Photogrammetric digital outcrop reconstruction, visualization with textured surfaces, and threedimensional structural analysis and modeling: Innovative methodologies applied to fault-related dolomitization (Vajont Limestone, Southern Alps, Italy). Geosphere; 11 (6): 2031-2048.

Blišt’an, P., Kovanič, L., Patera, M., Hurčík, T. (2019). Evaluation quality parameters of DEM generated with low-cost UAV photogrammetry and structure-from-motion (SfM) approach for topographic surveying of small areas. Acta Montanistica Slovaca, 24(3), 198-212.

Cipolla. R. (2008). Structure from motion. Online. [cit. 5.1.2020]. Dostupné na:<http://mi.eng.cam.ac.uk/ cipolla/publications/contributionToEditedBook/2008-SFM-chapters.pdf $>$.

Clini. P., Frapiccini, N., Mengoni, M., Nespeca, R., Ruggeri, L. (2016). SFM technique and focus stacking for digital documentation of archaeological artifacts. Archives of Photogrammetry. Remote Sensing \& Spatial Information Sciences. Vol. 41.

Csontos, L., Vörös, A. (2004). Mesozoic plate tectonic reconstruction of the Carpathian region, Palaeogeogr. Palaeoclimatol. Palaeoecol., 210, 1-56, doi: 10.1016/j.palaeo.2004.02.033

Fischler, M. A., Bolles R. C. (1981). Random Sample Consensus: A Paradigm for Model Fitting with Apphcatlons to Image Analysis and Automated Cartography. Online. [cit. 20.01.2013]. Dostupné ns:<http://www.ai.sri.com/pubs/files/836.pdf>.

Fraštia, M., Lišcák, P., Žilka, A., Pauditš, P., Bobál, P., Hroncek, S., Sipina, S., Ihring, P., Marčiš, M. (2019). Mapping of debris flows by the morphometric analysis of DTM: A case study of the Vrátna dolina Valley, Slovakia, Geograficky Casopis, Volume 71, Issue 2, Pages 101-120.

Fusiello, A., Irsara, L. (2011). Quasi-Euclidean epipolar rectification of uncalibrated images. Machine Vision and Applications. 22 (4): 663-670. 2011.

Gallay, M., Hochmuth, Z., Kaňuk, J. \& Hofierka, J. (2016). Geomorphometric analysis of cave ceiling channels mapped with 3-D terrestrial laser scanning: Hydrology and Earth System Sciences, 20, 5, 1827-1849. http://dx.doi.org/10.5194/hess-20-1827-2016

Granshaw, S.I. (2016), Photogrammetric Terminology: Third Edition. Photogram Rec, 31: $210-252$. doi:10.1111/phor.12146

Gross, P., Köhler, E., Samuel, O. (1984). Nové litostratigrafické členenie vnútrokarpatského paleogénu. Geologické práce, Správy, 81: 113-117.

Honti, R., Erdélyi, J. (2017). Segmentácia mračien bodov [Diploma thesis]. Slovenská technická univerzita v Bratislave. Stavebná fakulta. Katedra geodézie. Bratislava: SvF STU.61 s.

Janočko, J. (ed.); Gross, P., Polák, M., Potfaj, M., Jacko, S. ml., Rakús, M., Halouzka, R., Jetel, J., Petro, L., Kubeš, P., Buček, S., Köhler, E., Siráňová, Z., Zlínska, A., Halásová, E., Hamršmíd, B., Karoli, S., Žec, 
B., Fejdiová, O., Milička, J., Boorová, D. \& Žecová, K. (2000). Vysvetlivky ku geologickej mape Spišskej Magury. 1:50 000. ŠGÚDŠ, Bratislava, 174 pp.

Joglekar, J., Gedam, S. S., Mohan, B. K. (2014). Image matching using sift features and relaxation labeling technique -a constraint initializing method for dense stereo matching. IEEE Trans. Geosci. Remote Sens. 52 (9) 5643-5652. point clouds. "Computers \& Graphics. zv. 46. pp. 345-357. 2015.

Ke, Y., Sukthankar, R. (2004). PCA-SIFT: A more distinctive representation for local image descriptors. In: Proc. Computer Vision and Pattern Recognition (CVPR'04) (Pittsburgh. PA): II:506-513.

Lague, D.; Brodu, N.; Leroux, J. Accurate 3D comparison of complex topography with terrestrial laser scanner: Application to the Rangitikei canyon (N-Z). ISPRS J. Photogramm. Remote Sens. 2013, 82, 10-26, doi:10.1016/j.isprsjprs.2013.04.009

Lowe, D. G. (2004). Distinctive image features from scale-invariant key points. In: International Journal of Computer Vision 60(2): 91-110. doi:10.1023/B: VISI.0000029664.99615.94.

Mach, L. (2012). SIFT: Scale Invariant Feature Transform. Automatické nalezení korespondencí mezi dvojicí obrázků. Online. [cit. 15.01.2013]. Dostupné na:<http://cgg.mff.cuni.cz/ pepca/ref/SIFT.pdf>.

Menegoni, N., Meisina, C., Perotti, C., Crozi, M. (2018). Analysis by UAV Digital Photogrammetry of folds and related Fractures in the Monte Antola Flysh Formation (Ponte Organasco, Italy). Geosciences, 8 (8), 299.

Pavelka, K.; Šedina, J.; Matoušková, E. (2018). High Resolution Drone Surveying of the Pista Geoglyph in Palpa, Peru. Geosciences, 8, 479.

Reshetyuk, Y. (2009). Terrestrial laser scanning: Saarbrücken, VDM Verlag Dr. Müller, 184 p.

Roncella, R., Forlani, G., Remondino, F. (2004). Photogrammetry for geological applications: Automatic retrieval of discontinuity orientation in rock slopes. Proceedings of SPIE-The International Society for Optical Engineering.

Schönberger. J. L., Frahm. J. M. (2016). Structure-from-motion revisited. In: Agapito. L. Berg. T. Kosecka. J. (eds) Proceedings of the IEEE Conference on Computer Vision and Pattern Recognition (CVPR). Las Vegas. NV. June 2016. New York. NY: Institute of Electrical and Electronics Engineers (IEEE).

Thatcher, H., Hill, D. P. (1991): Fault corelations in extensional and conjugate strike-slip environments and their implications. In: Geology, 19 (11), 1116-1120.

Triggs, B.; McLauchan, P. F., Hartley, R. I., Fitzgibbon, A. W. (1999). Bundle Adjustment - A Modern Synthesis. Proceedings of the International Workshop on Vision Algorithms: Theory and Practice. p.298372. September 21-22

Urban, R., Štroner, M., Křemen, T., Braun, J., Möser, M. (2018). A novel approach to estimate systematic and random error of terrain derived from UAVs: A case study from a post-mining site. Acta Montanistica Slovaca, 23(3), 325-336.

Vollgger, S. A., \& Cruden, A. R. (2016). Mapping folds and fractures in basement and cover rocks using UAV photogrammetry, Cape Liptrap and Cape Paterson, Victoria, Australia. Journal of Structural Geology, 85, $168-187$. 